Jurnal Skala Kesehatan

Politeknik Kesehatan Banjarmasin

Vol. 12, No. 1, Januari 2021

E-ISSN: 2615 - 2126, P-ISSN: 2087 - 152X

Journal homepage: http://www. ejurnalskalakesehatan-poltekkesbjm.com

\title{
AROMATERAPI CITRONELLA OIL TERHADAP PENINGKATAN NAFSU MAKAN PADA BALITA USIA 1-5 TAHUN DI POSYANDU TULIP KELURAHAN PAHANDUT PALANGKA RAYA
}

\author{
Happy Marthalena Simanungkalit', Sefentina Agustin ${ }^{1}$, Grisiana Wilianti $^{2}$ \\ 1,2,3Politeknik Kesehatan Palangka Raya \\ 2Balai Pelatihan Kesehatan Propinsi Kalimantan Tengah \\ Email: sefentina1997@gmail.com
}

\begin{abstract}
ABSTRAC: Toddlers aged 1-5 years are a group that is prone to nutritional problems. At this time the child is experiencing rapid growth and development, so that it requires adequate and nutritious food intake. Variations in food can increase appetite because of the shape, taste, and attractive color. Attractive shapes in the variety of foods can foster children's curiosity. The purpose of this study was to determine the effect of Citronella Oil aromatherapy on increasing appetite in toddlers aged 1-5 years at the Posyandu Tulip, Pahandut Village, Palangka Raya. This research was carried out for 7 days giving aromatherapy Citronella Oil before going to bed at night. The study design used a Pre Experiment research using One Group Pre-Post Design to 20 respondents with appetite problems. The statistical test used was the Mc Nemar Test. From the Mc Nemar Test results, it was found that $p$ value of appetite $=0,000$, then Ha was accepted, meaning that there was an influence of Citronella Oil aromatherapy on increasing appetite in children aged 1-5 years at Posyandu Tulip, Pahandut Palangka Raya Village. Based on the results of this study, researchers suggest that as an alternative therapy to increase appetite and information to parents of toddlers about the influence of aromatherapy citronella oil so as to increase toddlers' appetite.
\end{abstract}

Keywords: Citronella Oil Aromatherapy, Increased appetite, Toddlers aged 1-5 years

Copyright @ 2021 Jurnal Skala Kesehatan.

Politeknik Kesehatan Banjarmasin

All rights reserved

Corresponding Author :

Happy Marthalena Simanungkalit,

Poltekkes Kemenkes Palangkaraya

Email : sefentina1997@gmail.com 
ABSTRAK: Anak balita yang berusia 1-5 tahun merupakan kelompok yang rawan terhadap masalah gizi. Pada masa ini anak mengalami pertumbuhan dan perkembangan yang sangat pesat, sehingga membutuhkan asupan makanan yang cukup dan bergizi. Variasi makanan dapat meningkatkan nafsu makan dikarenakan bentuk, rasa, warnanya berbentuk menarik. Bentuk yang menarik pada variasi makanan dapat menumbuhkan rasa ingin tahu anak. Tujuan penelitian ini adalah untuuk mengetahui adanya pengaruh aromaterapi Citronella Oil terhadap peningkatan nafsu makan pada balita usia 1-5 tahun di Posyandu Tulip Kelurahan Pahandut Palangka Raya. Penelitian ini dilakukan selama 7 hari pemberian aromaterapi Citronella Oil sebelum tidur malam. Rancangan penelitian menggunakan penelitian Pre Eksperimen menggunak One Group Pre-Post Design terhadap 20 responden dengan masalah nafsu makan. Uji statistik yang digunakan adalah Mc Nemar Test Dari hasil uji Mc Nemar Test didapatkan $p$ value nafsu makan $=0,000$ maka Ha diterima, artinya ada pengaruh aromaterapi Citronella Oil terhadap peningkatan nafsu makan pada balita usia 1-5 tahun di Posyandu Tulip Kelurahan Pahandut Palangka Raya. Berdasarkan hasil penelitian ini, peneliti menyarankan agar sebagai terapi alternatife untuk peningkatann nafsu makan dan informasi kepada orang tua balita tentang pegaruh aromaterapi citronella oil sehingga dapat meningkatkan nafsu makan balita.

Kata Kunci : Aromaterapi Citronella Oil, Peningkatan nafsu makan, Balita usia 1 5 tahun

\section{PENDAHULUAN}

Menurut World Health Organization (WHO) Anak balita yang berusia 1-5 tahun merupakan kelompok yang rawan terhadap masalah gizi. Pada masa ini anak mengalami pertumbuhan dan perkembangan yang sangat pesat, sehingga membutuhkan asupan makanan yang cukup dan bergizi. Pertumbuhan dan perkembangan balita merupakan suatu hal yang perlu mendapat perhatian besar

Prevalensi masalah kesulitan makan menurut klinik perkembanganan anak dari Affiliated program for children development di University George Town mengatakan 6 jenis kesulitan makan pada anak yaitu hanya mau makan makanan cair atau lumat: $27,3 \%$, kesulitan menghisap, mengunyah atau menelan: $24,1 \%$, kebiasaan makan yang aneh dan ganjil: $23,4 \%$, tidak menyukai variasi banyak makanan: $11,1 \%$, keterlambatan makan sendiri: $8,0 \%$, mealing time tantrum: $6,1 \%$ (Judarwanto, 2017). Menurut Riskesdas (2018) didapatkan hasil prevalensi kesulitan makan sebesar 33,6\%, 44,5\% diantaranya menderita malnutrisi ringan sampai sedang dan $79,2 \%$ dari subjek penelitian telah mengalami kesulitan makan lebih dari 3 bulan

Hasil penelitian Sudibyo \& Mulyani (2017), kelompok usia terbanyak mengalami kesulitan makan adalah usia 1 sampai 5 tahun (58\%), dengan jenis kelamin terbanyak laki-laki (54\%). (43\%) subjek memiliki status gizi kurang. Kesulitan makan sebanyak 50 orang dari 109 orang subjek (45,9\%). Gejala klinis esofagitis refluks ditemukan dalam jumlah yang sama (45,9\%). Menghabiskan makanan kurang dari sepertiga porsi $(27,5 \%)$, menolak makan $(24,8 \%)$ dan anak rewel, merasa tidak senang atau marah $(22,9 \%)$, hanya menyukai satu jenis makanan $(7,3 \%)$ hanya mau minum susu $(18,3 \%)$, memerlukan waktu $>1$ jam untuk makan $(19,3 \%)$ dan mengemut $(15,6 \%)$. Keluhan $72 \%$ telah dialami lebih 
dari 6 bulan, 50\% memiliki keluhan gangguan kenaikan berat badan, 22\% rewel, $12 \%$ nyeri epigastrium, $10 \%$ back arching, dan $6 \%$ nyeri menelan serta sering muntah.

Menurut Profil Kesehatan Kota Palangka Raya (2017) Jumlah Posyandu di Kota Palangka Raya sebanyak 143 posyandu tetapi Posyandu yang aktif hanya $40 \%$ atau sebanyak 57 Posyandu. Ditemukan kasus Gizi Kurang (0,8\%), Gizi Baik $(62,8 \%)$, Gizi Sedang (60,5\%) dari 8.319 balita yang ditimbang baik di Puskesmas ataupun Posyandu di Kota Palangka Raya. Salah satu penyebab gangguan nafsu makan akan mempengaruhi staus gizi balita.

Berdasarkan beberapa penelitian sumber daun sereh digunakan sebagai penambah nafsu makan, tanaman sereh digunakan sebagai peluruh air seni, peluruh keringat, peluruh dahak, bahan untuk kumur dan penghangat badan sedangkan. Manfaat Citronella Oil dengan kandungan geraniol dan sitronelal yang paling tinggi menyebabkan peningkatan nafsu makan. Penggunaan aromaterapi saat ini juga dikembangkan dalam pelayanan kebidanan komplementer untuk meningkatkan nafsu makan pada balita usia 1-5 tahun. (Ketaren, 2014).

Ditemukan Puskesmas Pahandut di Kota Palangka Raya yang mengalami balita dengan gizi kurang $(0,5 \%)$ serta keluhan para ibu tentang anaknya yang sulit makan. Puskesmas Pahandut memiliki 14 Posyandu yang aktif. Posyandu Tulip dengan balita usia 1-5 tahun yang terdaftar berjumlah 50 balita terdiri dari gizi kurang 2,5\%, gizi sedang $10 \%$, gizi baik 42,5\%. Berdasarkan hal tersebut diatas, peneliti tertarik mengambil judul "Aromaterapi Citronella Oil Terhadap Peningkatan Nafsu Makan Pada Balita Usia 1-5 tahun di Posyandu Tulip Kelurahan Pahandut Palangka Raya"

Tujuan penelitian ini untuk mengetahui apakah ada pengaruh Aromaterapi Citronella Oil Terhadap Peningkatan Nafsu Makan Pada Balita Usia 1-5 tahun di Posyandu Tulip Kelurahan Pahandut Palangka Raya

\section{METODE DAN BAHAN}

Penelitian ini menggunakan jenis penelitian pre eksperiment dan menggunakan rancangan penelitian one group pretest-postest. Perhitungan sampel menggunakan Rumus Lameshow Penelitian pre eksperiment merupakan penelitian yang menguji cobba suatu intervensi pada sekelompok subyek dengan atau tanpa kelompok pembanding namun tidak dilakukan randominasi untuk memasukkan subyek ke dalam kelompok perlakuan atau kontrol (Dharma Kusuma, 2012, hlm.93). Rancangan penelitian one group pretest-postest design merupakan penelitian yang tidak ada kelompok pembanding (control), tetapi sudah dilakukan observasi pertama (pretest) yang memungkinkan peneliti dapat menguji perubahan-perubahan yang terjadi setelah adanya eksperimen (Notoatmodjo, 2011, hlm.57).

Populasi Penelitian adalah keseluruhan obyek penelitian atau obyek yang diteliti (Notoadmodjo,2010). Populasi penelitian ini balita usia 1-5 tahun terdaftar di Posyandu Tulip Pahandut Palangka Raya

Sampel adalah sebagian atau wakil populasi yang diteliti. Sampel dalam penelitian ini adalah balita usia 1-5 tahun yang nafsu makannya menurun memenuhi kriteria inklusi dan ekslusi di Posyandu Tulip. Pengambilan sampel dalam penelitian ini dari jurnal penelitian Mega Pramijantoro dkk tahun 2016 dengan menggunakan rumus Lameshow Menurut perhitungan diatas, minimal sampel pada penelitian ini adalah 20 balita. Penelitian ini memiliki kriteria inklusi dan ekslusi sampel. Kriteria 
inklusi adalah karakteristik umum subjek penelitian dari suatu populasi target dan terjangkau yang akan diteliti. Sampel dalam penelitian ini adalah balita yang berusia 1-5 tahun sebanyak 20 balita.

Analisis univariat dilakukan untuk melihat gambaran data secara deskriptif. Data yang digunakan merupakan data kategorik dan numerik. Analisis univariat dalam penelitian ini dilakukan untuk melihat gambaran deskriptif atau data proporsi variabel independen dan variabel dependen. Variabel independen dalam penelitian ini adalah pemberian aromaterapi, sedangkan variabel dependen adalah nafsu makan pada balita usia 1-5 tahun serta variabel confounding adalah kebiasaan jajan pada balita. Analisis bivariat dilakukan terhadap dua variabel yang diduga berhubungan atau berkorelasi. Uji Mc Nemar digunakan pada penelitian ini yang membandingkan sebelum dan sesudah diberikan perlakuan pemberian pada kelompok sampel. Dengan non-parametrik test Apakah ada perbedaan yang berpengaruh dan tidak berpengaruh.

\section{HASIL DAN PEMBAHASAN}

Tabel 4.1 Distribusi Frekuensi Berdasarkan Peningkatan Nafsu Makan Pada Balita Usia 1-5 Tahun Sebelum Diberikan Aromaterapi Citronella Oil Di Posyandu Tulip KelurahanPahandut Palangka Raya

\begin{tabular}{lccc}
\hline & Variabel & F & $\%$ \\
\hline Peningkatan Nafsu Makan Sebelum Diberikan Aromaterapi & & \\
Nafsu Makan Menurun & & 20 & $100 \%$ \\
Nafsu Makan Meningkat & Total & 0 & $0 \%$ \\
\hline & $\mathbf{2 0}$ & $\mathbf{1 0 0} \%$
\end{tabular}

Tabel 4.2 Distribusi Frekuensi Berdasarkan Peningkatan Nafsu Makan Pada Balita Usia 1-5 Tahun Sesudah Diberikan Aromaterapi Citronella Oil Di Posyandu Tulip Kelurahan Pahandut Palangka Raya

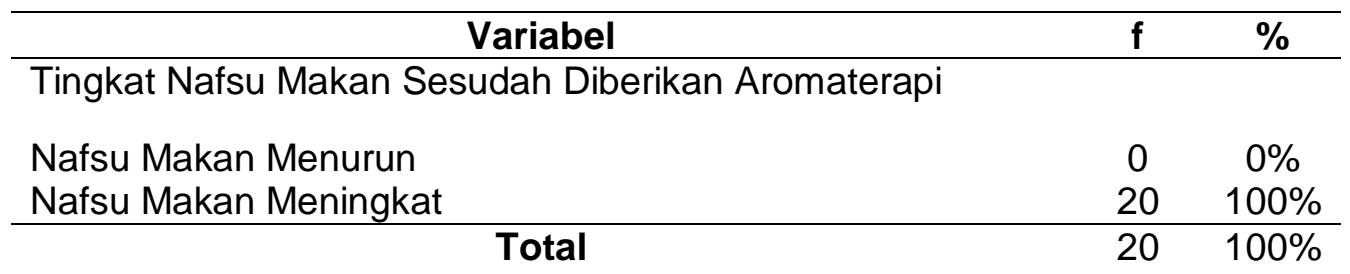

Tabel 4.3 Distribusi Berdasarkan Kebiasaan Jajan Pada Balita Usia 1-5 tahun Sebelum Diberikan Aromaterapi Citronella Oil

\begin{tabular}{rccc}
\hline \multicolumn{1}{c}{ Variabel } & f & $\%$ \\
\hline Kebiasaan Jajan & & \\
Jajan Lebih Dari 3 kali sehari & 15 & $75 \%$ \\
Jajan Kurang dari 3 kali sehari & 5 & $25 \%$ \\
\hline \multicolumn{1}{c}{ Total } & 20 & $100 \%$
\end{tabular}


Tabel 4.4 Pengaruh Sesudah Diberikan Aromaterapi Citronella Oil Terhadap Peningkatan Nafsu Makan Pada Balita Usia 1-5 Tahun Di Posyandu Tulip Kelurahan Pahandut Palangka Raya

\begin{tabular}{lccc}
\hline \multicolumn{1}{c}{ Variabel } & f & $\%$ & p.value \\
\hline & & & \\
\hline Tingkat Nafsu Makan Sesudah Diberikan Aromaterapi & & & \\
& & & \\
Nafsu Makan Menurun & 0 & $0 \%$ & \\
Nafsu Makan Meningkat & 20 & $100 \%$ & $.000^{\text {b }}$ \\
\hline \multicolumn{1}{c}{ Total } & & $100 \%$ &
\end{tabular}

\section{PEMBAHASAN}

Peningkatan Nafsu Makan Balita Usia 1-5 Tahun Sebelum Diberikan Aromaterapi Citronella Oil Di Posyandu Tulip Kelurahan Pahandut Palangka Raya

Karakteristik responden sebagaimana ditampilkan pada tabel 4.1 tentang peningkatan nafsu makan balita sebelum diberikan aromaterapi citronella oil berdasarkan tingkat nafsu makan balita yang sebelum diberikan aromaterapi Citronella Oil sejumlah $20(100 \%)$ yang tidak nafsu makan dan balita yang nafsu makan sejumlah $0(0 \%)$. Karakteristik balita dibagi menjadi dua yaitu:

- Anak usia 1-3 tahun

Usia 1-3 tahun merupakan konsumen pasif artinya anak menerima makanan yang disediakan orang tuanya. Laju pertumbuhan usia balita lebih besar dari usia prasekolah, sehingga diperlukan jumlah makanan yang relatif besar. Perut yang lebih kecil menyebabkan jumlah makanan yang mampu diterimanya dalam sekali makan lebih kecil bila dibandingkan dengan anak yang usianya lebih besar oleh sebab itu, pola makan yang diberikan adalah porsi kecil dengan frekuensi sering. - Anak usia prasekolah (3-5 tahun)

Usia 3-5 tahun anak menjadi konsumen aktif. Anak sudah mulai memilih makanan yang disukainya. Pada usia ini berat badan anak cenderung mengalami penurunan, disebabkan karena anak beraktivitas lebih banyak dan mulai memilih maupun menolak makanan yang disediakan orang tuanya.Kesulitan makan pada anak merupakan salah satu gangguan perkembangan yang dapat terjadi pada bayi atau anak sehat. Sekitar $25 \%$ anak dengan perkembangan normal dan $80 \%$ anak dengan gangguan perkembangan dilaporkan mempunyai masalah makan. Kriteria nafsu makan menurun : memilih makanan, tidak menghabis sepertiga makanan dipiring kecil, makan hanya sedikit $1 \mathrm{x} /$ sehari bahkan tidak sama sekali, sulit untuk mencoba makanan baru dan menghindari beberapa jenis makanan, dan memiliki makanan yang sangat disukainya. Seperti yang dikemukakan tentang keadaan nafsu makan balita merupakan masalah umum balita dimana balita mengalami penurunan nafsu makan (Diyana Purba, 2015).

Peningkatan Nafsu Makan Balita Usia 1-5 Tahun Sesudah Diberikan Aromaterapi Citronella Oil Di Posyandu Tulip Kelurahan Pahandut Palangka Raya 
Karakteristik tingkat nafsu makan balita sesudah diberikan aromaterapi citronella oil berdasarkan tingkat nafsu makan balita yang sesudah diberikan aromaterapi Citronella Oil sejumlah $20(100 \%)$ yang tidak nafsu makan dan balita yang nafsu makan sejumlah $0(0 \%)$.

Usia prasekolah merupakan masa-masa penting dalam membentuk kebiasaan makan sehat pada anak. Tahapan ini, anak mulai belajar untuk bias makan sendiri, sehingga diperlukan contoh yang dapat menunjukan dan mengarahkan perilaku makan yang baik bagi anak. Sebagai bagian dari perkembangan kehidupan sosial, anak mempelajari sesuatu dengan meniru perilaku orang-orang disekitarnya termasuk perilaku makan (Brown, 2011).

Kebiasaan Jajan Pada Balita Usia 1-5 tahun Sebelum Diberikan Aromaterapi Citronella Oil

Kebiasaan jajan pada balita usia 1-5 tahun sebelum diberikan aromaterapi citronella oil sejumlah 20 (100\%) balita dengan jajan lebih dari 3 kali sehari. Dan balita dengan jajan kurang dari 3 kali sehari sejumlah 0 (100\%).

Jajanan adalah makanan atau minuman siap santap sebagai camilan dan makanan cepat saji. (Jurnal Ilmu Kesehatan 2015). Kategori balita yang suka jajan yaitu : Jajan lebih dari 3x sehari di sekolah atau diluaran rumah, Jajan makanan hygenis atau junkfood dan makan jajanan yang banyak mengandung zat pengawet, pewarna atau perasa yang berlebihan. Pemberian zat gizi yang tepat pada usia ini akan membantu pertumbuhan fisik dan juga mentalnya.

a.Pengaruh aromaterapi Citronella Oil terhadap peningkatan nafsu makan pada balita usia 1-5 tahun

Berdasarkan hasil uji McNemar T-test, menunjukan bahwa kedua data menunjukan $p$-value $=0.000^{\mathrm{b}}<0,005$ dimana nilai ini lebih besar dari $\alpha=0,05$ yang Ho ditolak dan Ha diterima serta dapat dilihat perbedaan antara peningkatan nafsu makan pada balita sebelum diberikan aromaterapi dan setelah diberikan aromaterapi. Dan perubahan berat badan pada balita sebelum diberikan aromaterapi dan setelah diberikan aromaterapi. Jadi dapat disimpulkan bahwa terdapat pengaruh Aromaterapi Citronella Oil terhadap peningkatan nafsu makan pada balita usia 1-5 tahun

Penelitian ini dilakukan oleh peneliti dengan cara memberikan aromaterapi selama 7 hari diberikan 1x/hari sebanyak 3 tetes dan dicampurkan dengan $40 \mathrm{ml}$ air dimasukkan ke dalam diffuser yang akan dinyalakan selama kurang lebih 30 menit sebelum tidur malam. Dilakukan post-test setelah hari ke 8 untuk mengetahui hasil dari pemberian aromaterapi dengan jumlah sampel 20 balita usia 1-5 tahun dengan kriteria inklusi dan ekslusi berdasarkan hasil uji McNemar T-test, menunjukan bahwa kedua data menunjukan $p$-value $=0.000^{\mathrm{b}}<0,005$ sedangkan penelitian Ery Fatmawaty (2016) yaitu pemberian aromaterapi terhadap balita usia 2-5 tahun dengan dioleskan kebagian leher balita, membuktikan bahwa terdapat peningkatan nafsu makan pada balita setelah diberikan aromaterapi. Terdapat perbedaan yang tidak bermakna $(P>0,005)$ pada asupan makanan pokok, sayuran sedangkan terdapat perbedaan yang bermakna pada asupan lauk hewani.

Peningkatan nafsu makan yang signifikan pada responden tersebut, terjadi dikarenakan pemberian Aromaterapi Citronella Oil selama 7 hari sebelum responden tidur pada malam hari. Aromaterapi minyak sereh wangi secara psikologis dan fisik melalui aktivasi system limbic memberikan sinyal bau akan dihantarkan ke area olfaktorius bagian lateral pada kortek serebri dan selanjutnya dihantarkan ke system limbic. Melalui hypothalamus sinyal ini akan diolah dan dihantar ke amigdala dan menghasilkan emosi terhadap aroma yang sudah 
dihirup, selain itu bila rangsangan dihantarkan ke system saraf pusat otonom di medulla spinalis parasimpatis maka akan mengaktifkan efek penghambatan system simpatis dan penguatan system. Hal ini akan merangsang memori dan respons emosional. Hipotalamus berperan sebagai relay dan regulator, memunculkan pesan-pesan yang harus disampaikan ke bagian lain otak serta bagian badan yang lain. Pesan yang diterima itu kemudian diubah menjadi tindakan yang berupa pelepasan senyawa neurokimia seperti serotonin dan enkefalin yang menyebabkan euphoria, relaks, dan sedative (Eri Fatmawati 2016).

\section{KESIMPULAN}

1.Peningkatan Nafsu Makan Balita Sebelum Diberikan Aromaterapi Citronella Oil Di Posyandu Tulip Kelurahan Pahandut Palangka Raya berdasarkan tingkat nafsu makan balita yang sebelum diberikan aromaterapi Citronella Oil sejumlah 20 $(100 \%)$ yang tidak nafsu makan dan balita yang nafsu makan sejumlah $0(0 \%)$.

2.Peningkatan Nafsu Makan Balita Sesudah Diberikan Aromaterapi Citronella Oil Di Posyandu Tulip Kelurahan Pahandut Palangka Raya berdasarkan tingkat nafsu makan balita yang sesudah diberikan aromaterapi Citronella Oil sejumlah 20 $(100 \%)$ yang tidak nafsu makan dan balita yang nafsu makan sejumlah $0(0 \%)$.

3.Kebiasaan Jajan Pada Balita Usia 1-5 tahun Sebelum Diberikan Aromaterapi Citronella Oil kebiasaan jajan pada balita usia 1-5 tahun sebelum diberikan aromaterapi citronella oil sejumlah 20 (100\%) balita dengan jajan lebih dari 3 kali sehari. Dan balita dengan jajan kurang dari 3 kali sehari sejumlah 0 (100\%).

4.Ada Pengaruh Aromaterapi Citronella Oil terhadap peningkatan nafsu makan pada balita usia 1-5 tahun di Posyandu Tulip Wilayah Kerja Puskesmas Pahandut dengan nilai $p$-value $=0.000 b<0,005$

\section{SARAN}

Manfaat Teori

- Meningkatkan kemampuan dan keterampilan peneliti dalam melaksanakan penelitian dan penulisan ilmiah, khususnya mengenai Aromaterapi Citronella Oil Terhadap Peningkatan Nafsu Makan Pada Balita Usia 1-5 tahun di Posyandu Tulip Kelurahan Pahandut Palangka Raya

- Meningkatkan pengetahuan serta pengalaman mahasiswa dalam hal penelitian, sehingga institusi mampu meluluskan mahasiswa yang berkompeten, serta hasil ini dapat dijadikan sumber referensi bagi mahasiswa lain tentang aromaterapi citronella oil terhadap peningkatan nafsu makan pada balita.

Manfaat Praktis

- Penelitian ini dapat digunakan sebagai terapi alternatife untuk peningkatann nafsu makan dan informasi kepada orang tua balita tentang pegaruh aromaterapi citronella oil sehingga dapat meningkatkan nafsu makan balita.

\section{DAFTAR PUSTAKA}

1. Dinas Kesehatan DIY, 2013, Profil KesehatanPropinsi DIY, Dinas Kesehatan Propinsi DIY, Yogyakarta

2. Jurnal IImu Kesehatan. 2015 Kriteria yang behubungan dengan terjadinya sulit makan pada anak balita

3. Notoadmodjo. 2010 Konsep dan Penerapan Metodologi

4. Profil Kesehatan Kota Palangka Raya Gizi Pada Balita. 2017

5. Sudibyo \& Mulyani. 2017 Jurnal IImiah Kesehatan. 5 (1) : 20-25. Jakarta 